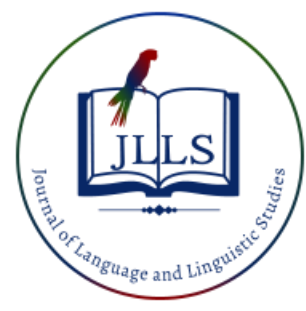

Available online at www.jlls.org

JOURNAL OF LANGUAGE AND LINGUISTIC STUDIES

ISSN: 1305-578X

Journal of Language and Linguistic Studies, 17(3), 1582-1597; 2021

\title{
Bullying in trump's tweets through Covid-19: A pragmatic perspective
}

\author{
Hussein Hameed Ma'yuuf ${ }^{\text {a }}$ iD, Ibtihal Jasim Abbas ${ }^{\text {b }}$ iD \\ ${ }^{a, b}$ College of Education for Human Sciences, University of Babylon, Iraq
}

\section{APA Citation:}

Ma'yuuf, H. H \& Abbas, I. J. (2021). Bullying in trump's tweets through Covid-19: A pragmatic perspective. Journal of Language and Linguistic Studies, 17(3), 1582-1597. Doi: 10.52462/jlls.114

Submission Date:28/05/2021

Acceptance Date:15/08/2021

\begin{abstract}
Nowadays, everyone can witness the importance of the internet and the role it plays as a means of communication. Tweeter is one of the best social networking websites now. This type of social media, people create an online profile through enlisting personal facts and interests, connect with other users, and sharing updates of information that is posted daily (Hargittai and Hsieh, 2011: 47). Besides the positive sides that such media have, there are some negative issues that these media may reflect. Bulling is one of these negatives.

Pragmatically, this paper concerns itself with studying cyberbullying in Trump's tweeters. Consequently, the data will be analyzed according to some pragmatic theories like politeness, implicature, and pragmatic metaphor. The questions that the paper tries to answer are: (1) Does Trump use a direct bully or indirect one? (2) What are the polite strategies that Trump tries to use in order to minimize the effect of bullying? (3) Are there any implied meanings in Trump's tweeters that he wants to convey? To answer these questions, the following aims are put: (1) showing whether Trump uses an explicit bullying or an implicit one, (2) clarifying the polite strategies that Trump may use in his tweeters, (3) shedding light on the implied meanings in Trump's tweeters. Working on these aims, the following hypotheses are suggested: (1) Trump uses explicit and implicit bullying in his tweeters, (2) there are certain strategies that Trump follows in his bullying, and (3) there are some implied meanings (implicature) that Trump is behind.
\end{abstract}

Key words: bullying; pragmatics; speech act; impoliteness; implicature

\section{Introduction}

Broadly speaking, bullying is one of the most negative bahviours used in social media. It is used to show power or authority over others. At the present time and through the great spread of social media, bullying is used heavily to mock others. The first party bullies other no matter what harm one could cause to them. Among the different social media, people heavily bully via using tweeter.

Pragmatically, the phenomenon of bullying can be analysed. In other words, some pragmatic notions like speech acts, impoliteness, implicature, and deixis can be utilized. As for speech acts, there are some speech acts that are used heavily in bullying others. Regarding impoliteness, it shows how people bully others by threatening their positive faces. By deixis, some types of deixis are heavily used

\footnotetext{
${ }^{1}$ Corresponding author

Emailid: husm56@gmail.com
} 
than others, e.g., personal deixis than place or time diexis. Finally, bullying can be performed either by using explicature or implicature.

\section{Literature Review}

\subsection{Bullying}

Generally, bullying can be defined as the abuse and ill-treatment of other defenseless by someone stronger, or more dominant. In other words, bullying can be action, written or spoken words for intimidating or harassing an individual or to cause physical harm to others. Whereas, cyberbullying is the verbal bullying of others by using some anonymous electronic means of communication (e.g., posts or text messages) (Website 1).

Bullying is used heavily nowadays. Everyone bullies, no matter what harm one causes to others, someone has likely bullied others. There are many matters in the news in which bullying takes place. Bullying happens everywhere. Further, the chances that someone encounters in it are great. Everywhere in the world, bullying is used heavily particularly in schools and online communication (ibid).

Historically, the item "bully" could be traced back to the 1530s. (Harper, 2008:127). In its essential sense, bullying includes two entities, a bully or and a victim. The first entity, i.e. bully, abuses the second entity, i.e. victim, by using physical, verbal, or any means to gain a sense of dominant and power. Those types of actions could be direct (i.e. hitting, verbally assaulting face-to-face, etc.) or indirect (i.e. rumors, gossip, etc.).

Originally, the need to be survived is intuitive and common among humans. Survival can be connected directly with competing due to the unlimited variety of species as opposed to limited natural resources. At the beginning, there had been a continuous drive to out-perform others and get rid of obstacles. This survival instinct remained as it is as humans have evolved. Both forces have run over into the social, educational, and economic realms. This fact of competitive grading, though widespread in most societies, is variable across cultures depending on bases like ethics, traditions, and the policy of government. Unfortunately, the U.S. society unintentionally believes that success and wealth go together. This ideology helps in shaping a nation where bullying is accidentally instilled as a survival tactic from a very young age (Donegan, 2012:3).

From the moment that an American child gets into grade school, they are taught to be the top they can. This apparently cleared lesson could morph as a child advances throughout their education. Often, students learn corrupted ways to get ahead in the highest level of competitive educational and social systems which rank school presents. Those tactics of bullying may include compelling others for answers on assignments to gain higher marks. Those tactics are dangerous for the fact that once a student apprehends their effectiveness, students may construct a life style according to such tactics. To develop a habitual use of bullying tactics could lead to harmfully affecting a uncountable number of people as well as corrupting in the workplace (ibid).

\subsection{Traditional Bullying Vs. Cyberbullying}

The progression of technology is often associated with the progression of human societies. Essential innovations, like the Internet, have always changed how people communicate. Though those progresses have permitted humans to make great steps in many fields. Also, they have permitted procedures of transgression to be more widespread. This is obvious when taking into consideration how traditional bullying has been changed into a matter nowadays recognized as cyberbullying. While both, i.e. bullying and cyberbullying, are often comparable in terms of form and procedure. Also, they 
have several dissimilarities. Contrasting to normal bullying, cyberbullying allows the wrongdoer to hide their identity behind any digital means. This makes it easier for the wrongdoer to attack blows against a victim without having to see the victim's actual reaction. The effect that these technological devices have on people often leads them to say and do crueler things compared to what is typical in a traditional face-to-face bullying situation (Donegan, 2012:3).

\section{Method}

\subsection{Pragmatics}

Broadly speaking, pragmatics is a field of linguistics that studies the ways in which language is linked to the contexts of use. Thus, pragmatics is considered as a separate and coherent field of inquiry that studies language in context. It has been the essential focus of both linguistics and philosophy of language. Investigating standard pragmatic issues like deixis, presupposition, speech act, implicature, politeness theory, and information structure has been motivated by a variety of problems and stalemates encountered in analysing language in a significantly de-contextualized form (Slotta, 2018: 1). This paper focuses on the way Trump's tweeters have utilized some pragmatic phenomena like speech act, politeness, implicture and pragmatic metaphor.

\subsubsection{Speech Act of bullying}

Generally, the term 'speech act' is taken from Austin's work that is entitled How to Do Things with Words (1965). Speech act theory considers utterances and turns as real actions. It does not only consider language used in everyday communication, yet it studies change in speakers' behaviours as well as the listener at the time of communication.

At the beginning, Austin studied language from a different point of view and shed light on what is called statements of true and false, and truth conditions. For him, there are many possibilities in language, these possibilities are non-assertive categories which contain questions, commands, exclamations etc. Further, he studies language from non-conventional point-of-view which is a kind of reaction to the traditional view of language. Besides Austin, John Searle contributed a lot to the speech act theory.

Linguistically, the speech act of bullying can be defined as an act where the speaker knows that he is doing something bad. A person who practices bullying does not always fear the public disapproval, and may act openly. In bullying, there is a speaker and a hearer, one of them has more power than the other, i.e. speaker. The speaker bullies others for social, political, or racial purposes (Anna Wierzbicka, 1987: 397).

Rarely, bullying is performed directly, in that when practicing bullying, the speaker does not admit that what he does is bullying. As such, the performative "bully" is not used. An example of direct bullying:

1. I bully you if you have realized!

Usually, it is used indirectly. Most of the used examples are indirect, in that there is no use for the performative verbs.

For example,

2. Just watch Melania Trump speech, for some reason it made me think of the blueberry girl from Willy Wonka.

In this example, the speaker is bullying Melania because of her address. That is, he is calling her blueberry girl. Blueberry girl is an actress who has a role of girl who blows up like a balloon. As in the below figure. 


\section{Just watched Melania Trump speech. \\ For some reason it made me think of the blueberry girl from Willy Wonka.}

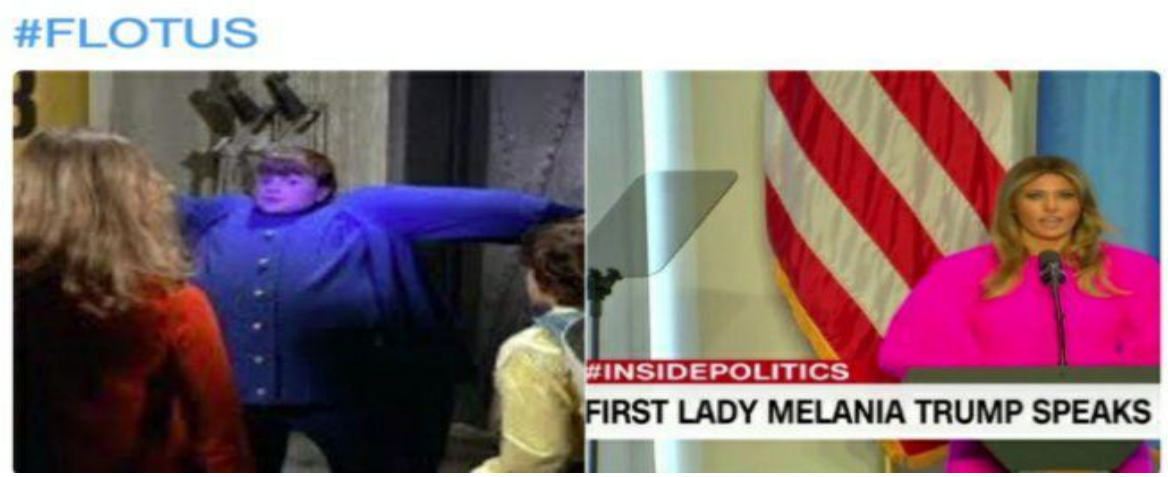

Figure 1. A Tweeter about Melania dress

Here, the study tries to put some conditions for bullying. If the speeches follow these conditions, they can be regarded as bullying.

Before setting up the conditions for bullying, felicity conditions must be defined. According to Bublitz, Jucker, and Schneider (2011: 40-1), "to combine and systemize language-internal and language-external factors, Speech Act Theory uses a set of conditions called "felicity conditions" (henceforth FCs). Thus, for SAs to be felicitous, they must be produced in accordance with these conditions. Further, since language is described as a highly-governed form of behaviour, so it is specified in the FCs of SAT. Mey (2009: 1003) indicates that Searle (1969) classifies the FCs into the following":

i. Propositional Content Conditions (PCCs): they refer to what the SA is about.

ii. Preparatory Conditions (PCs): they state the real world basics for the SA.

iii. Essential Conditions (ECs): they define the act being performed in the sense that the speaker has the intention that his utterance will count as an act, then such intention will be recognized by the listener.

iv. Sincerity Conditions (SCs): they have to be satisfied if the speech act is performed sincerely.

According to the abovementioned conditions, the study sets the following conditions for bullying.

1. Propositional Content Conditions: A expresses something bad.

2. Preparatory Conditions (PCs): (i) $\mathrm{S}$ is able to do A. (ii) $\mathrm{S}$ is seeking power and control over $\mathrm{H}$.

3. iii. Essential Conditions (ECs): (i) $\mathrm{S}$ has the intention to perform $\mathrm{A}$. (ii) $\mathrm{H}$ realizes $\mathrm{A}$ and he is harmed by it.

4. Sincerity Conditions (SCs): if the above conditions are satisfied, the act is sincerely performed.

\subsubsection{Politeness Theory}

Politeness Theory is another theory of pragmatics. According to Yule (1996:60), politeness is the way that a speaker can employ certain strategies as an attempt to show someone public self-image. Whereas Cutting (2003: 45) states that politeness refers to the different choices of language use made by a speaker. Actually, it is a linguistic phenomenon that helps people to be friendly to each other.

There are many notions within the theory of politeness. Face and politeness is one of them. Generally, the positive social value is the definition of "face". Such value is attributed to the person by 
himself (Goffman, 1967: 5). Further, Brown and Levinson (1987:61) have defined face as the public self-image that is claimed by everyone to be involved within a society. Additionally, face has two aspects: positive and negative. Having the desire that someone's actions not to be unimpeded through others is called "negative face". Whereas, having the desire that someone's actions are desirable through others is called "positive face". In other words, negative face is the need of people to be free from other people judgments, while positive face is the need of people to be accepted by others.

Being in the area of face, Yule (1996:61) suggests another term that is "Face Threatening Act". Face Threatening Act occurs when a speaker says something that threatens listener's self-image.

Commonly the function of language is a means of communication among people and to create harmony among them. Having harmony, a language must be understandable. As such, politeness is one of the tools that makes language understandable. For Brown and Levinson (1987:61), politeness has the aim of minimizing Face Threatening Act.

If someone wants to perform Face Threatening Act and at the same time, he wants to preserve the face of those involved, he/she will carry out politeness work appropriate to the face threat of the act. Brown and Levinson suggest five strategies to perform face threatening act (Culpeper: 1996: 356).

\section{1) Bald on record}

According to this strategy, Face Threatening Act is performed exactly, obviously, and easily.

\section{2) Positive politeness}

Restoring the listener's positive face needs is the aim of this strategy.

\section{3) Negative politeness}

Restoring the listener's negative face needs is the aim of this strategy.

\section{4) Off-record}

To have this strategy, the speaker performs FTA ambiguously. That is, he uses a language that makes the listener suspects that this is FTA (Grice, 1975).

\section{5) Withhold the FTA}

Avoiding FTA is the aim of the speaker in this strategy.

\subsubsection{Impoliteness}

Having bullying as the main topic is necessary to talk about impoliteness. In other words, performing bullying is an impolite behavior in itself. As such, this section is devoted to talk about impoliteness pragmatically.

According to Leech (1983: 82), the main function for politeness principles is to keep social harmony. From that it can be concluded that threatening others' faces can be described as impolite or it can cause disharmony among people (Culpeper et al. 2003: 1546).

Actually, there is no clear theoretical framework for impoliteness neither a theory. Yet the term "impoliteness" is developed through the studies that done in this area in addition to the contribution of Culpeper et al. (2003). As an attempt to define impoliteness, Culpeper et al. (2003: 154) states that impoliteness is "a negative attitude which occurs in specific context towards specific behaviors." Such notion is reinforced by social expectations regarding behavior. Such expectations include identity for individual or a group within a society. In other words, some behaviors are considered as impolite when they come in contrast to how an individual is expected to be (Culpeper, 2011: 23).

As with politeness, there are some strategies for impoliteness in which the study will summarize them below. These strategies are suggested by Culpeper (1996) depending on Brown and Levinson (1987) strategies.

\section{1) Bald on record impoliteness}


Here, the speaker performs FTA directly as an attempt to express that his threatening is performed intentionally.

\section{2) Positive impoliteness}

The main purpose of this strategy is to attack the positive face of the listener. Performing this strategy requires many sub-strategies like ignoring, excluding, disinterested, being unconcerned, being unsympathetic, using unsuitable identity markers, using ambiguous language, having disagreement, using taboo words, and calling the other names.

\section{3) Negative impoliteness}

Attacking the negative face needs of a listener is aim of this strategy. In other words, the speaker tends to attack the listener's need to have freedom. As with the previous strategy, it involves some sub-strategies like fighting, belittling, mocking, being condescending, being acted non-seriously, "invading the other's space, explicitly associating the other with a negative aspect, and putting the other's indebtedness on record."

\section{4) Off-record impoliteness}

Here, the speaker tends to perform FTA implicitly. In other words. The speaker uses implicature when performing this strategy.

\section{5) Withhold politeness}

Having no politeness, it gives the chance for impoliteness to occur. For example, if someone fails to express gratitude, it means that he is impolite.

\section{Functions of Impoliteness}

According to Culpeper (2011: 223), there are three functions of impoliteness. They are:

\section{1) Affective impoliteness}

This functions involves the type of feelings that has a relation to outburst feelings. In other words, it occurs within anger feelings.

The following example shows an impoliteness strategies performed by a girl who is angry at her friend.

Girl: How dare you walk out on me like that! You can't

just treat me like that! Who the hell you think you are?

Boy: I need to go. I have other things to do

\section{2) Coercive impoliteness}

It occurs between two parts: producer and target. Its purpose is to rearrangements of values in the benefit of producer. Usually, it occurs in a society with different structures. The following example makes it clear:

Manager: I want the file for my tomorrow's presentation on

my desk in 10 minutes and bring a cup of coffee

from the coffee shop across the street.

Secretary : Err... Okay, but I'm having my lunch right now. Is

it okay if I do that after I finished?

Manager : I don't care about what you are doing. 10 minutes.

\section{3) Entertaining impoliteness}


As with the previous function, here must be a producer and a target. The target is the victim at the same time. Further, the producer tends to exploit the target for the purpose of entertaining on the cost of the target. The following example makes it clear:

Girl A : What a pretty dress you wear tonight.

Girl B : Oh, thanks. I made it myself.

Girl A : Wow, really? 'Cause I'd like to have one.... for my cat.

\subsection{Implicature}

In communication, sometimes interlocutors find themselves obliged to say something implicitly. As such, using implicature is required. In other words, implicature means what is said is different from what is implied. That is, what is wanted to be said is done indirectly (Wright, 1975:379). The following example makes it clearer.

\section{A: What time is it?}

\section{B: The newspaper has not arrived yet.}

Here, (A) is clearly asking about time as it appears in the watch. On the other hand, (B) is answering indirectly. That is, he may want to say 'I don't know what time it is, yet the newspaper that we are used to have at a specific time has not been reached yet.' As such, it is understood that one has to get the meaning of implicature through context.

Generally, there are two types of implicature: conventional and conversational. Conventional implicature is defined as "the implication which is general and conventional". In other words, conventional implicature has a relation to language usage. It is not temporary that means it has a meaning that continues for a long time (Brown and Yule, 1983: 31). An example for conventional implicature is:

a. John is handsome but he rides $C D 70$.

b. John is handsome.

c. John rides $C D 70$.

d. There is a contradiction between (b) and (c).

Here, the speaker in (a) says that John is handsome with a charming face, yet he rides CD 70. Actually, riding CD 70 is an indication for old man. As such, the general meaning is that John is handsome although he is an old man.

Whereas conversational implicature means the implied meaning in conversations. Contrary to conventional implicature, conversational implicture is temporary and has no relation to conventional utterances. Further, implicature, here, is a mixture of language and context that implicature may be derived from (Black, 2006: 25). an example about conversational implicture:

A: Do you like linguistics?

B: Well, let's just say I don't jump for joy before class.

Through the above conversation, A's question is clear, whereas B's answer has an implied meaning. That is, B wants to say that he is uninterested in linguistics since he has no joy before class.

\subsection{The Model}

The model that this paper considers is an eclectic model. That is, the selected data is analyzed according to three theories: speech act, impoliteness and implicature. More specifically, if the selected data has the conditions of bullying as a speech act, it will be regarded as bullying. Further, if the 
strategies of impoliteness are existed in the selected data, it is bullying. Finally, sometimes implicature may be employed to express bullying. See figure (1)

Figure (1) The Model

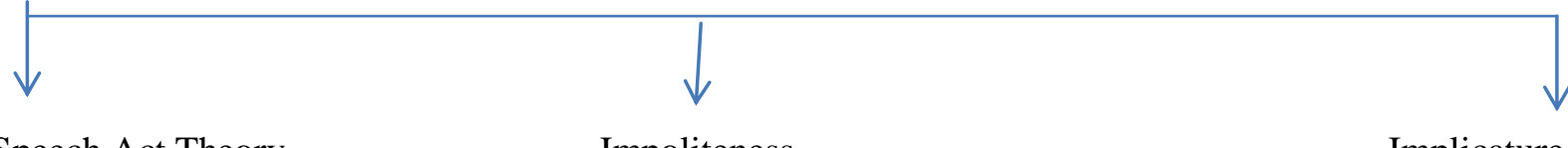

Speech Act Theory

Impoliteness

Bald on record impoliteness

Positive impoliteness

Negative impoliteness

Off-record impoliteness

Withhold politeness

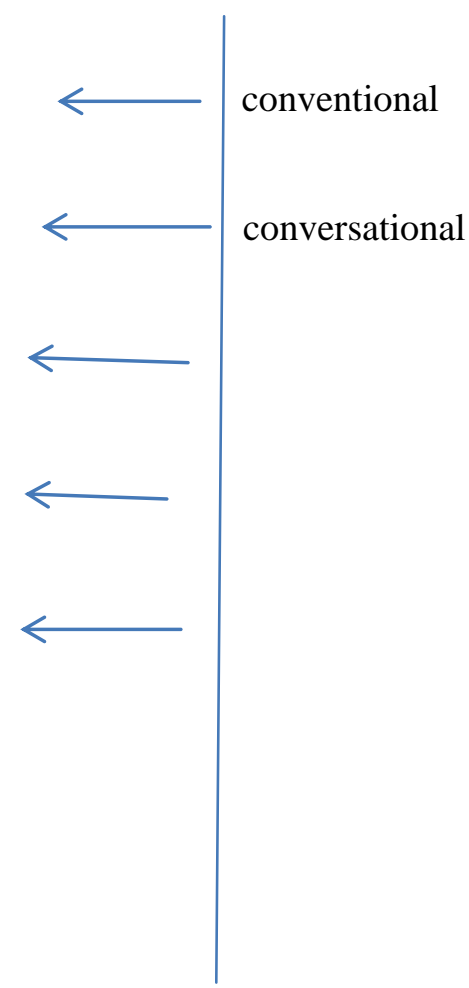

Implicature

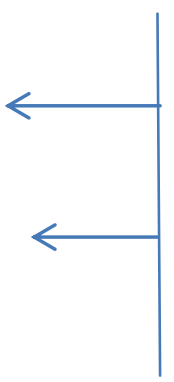

Figure 1. The model of the study based on Searle (),Culpeper et al. (2003), and Grice (1988)

\section{The Analysis}

\subsection{Data Description}

The current paper has chosen five tweets for Trump in which he is bullying China because of Covid-19. Recently, bullying China is a critical issue in the political domain. That is, Trump believes that China is the responsible one for this virus. As such, he starts using the term "Chinese Virus" as an attempt to bully them, i.e. Chinese people.

\section{Tweet (1)}


Donald J. Trump

(1) realDonaldTrump

\section{I always treated the Chinese Virus very seriously, and have done a very good job from the beginning, including my very early decision to close the "borders" from China - against the wishes of almost all. Many lives were saved. The Fake News new narrative is disgraceful \& false!}

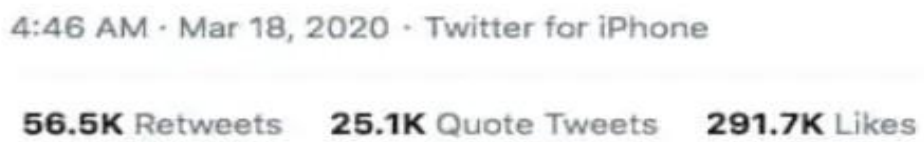

Twitte

\section{Speech Act}

1. Propositional Content Conditions: This tweet expresses something bad. That is, using the term "China Virus" is bad for China.

2. Preparatory Conditions (PCs): Trump plays the role of being control over China.

3. iii. Essential Conditions (ECs): (i) Trump has the intention to perform bullying. (ii) Chinese people realize that they are harmed by Trump's speech.

4. Sincerity Conditions (SCs): Since the above conditions are satisfied, it is clear that bullying is sincerely performed.

\section{Impoliteness Theory}

\section{1) Bald on record impoliteness}

Here, Trump performs FTA directly as an attempt to express that his terminology about bullying is performed intentionally.

\section{2) Positive impoliteness}

In this strategy, Trump tries to attack the positive face of Chinese people by accusing them as the main source for Corona Virus. Further, attacking Chinese positive face is done through being un sympathetic.

\section{3) Negative impoliteness}

According to this strategy, Trump attacks Chinese people negative face by having no freedom from being accused of the main reason of Corona Virus. He performs this strategy by mocking them.

\section{4) Off-record impoliteness}

This strategy is not existed in Trump's tweet.

\section{5) Withhold politeness}

Using the expression "Chinese Virus" has no sense of politeness. As such, it gives the chance for impoliteness to occur. 


\section{Tweet (2)}

\section{Biden FAILED BADLY with the Swine Flu. It was the Gang That Couldn't Shoot Straight". He didn't have a clue. We have done an incredible job with the much tougher China Virus!}

\section{8:26 AM - Sep 18, 2020 - Twitter for iPhone}

\subsection{K Retweets $\quad \mathbf{5 . 4 K}$ Quote Tweets $\quad$ 117.3K Likes}

\section{Twitter}

\section{Speech Act}

1. Propositional Content Conditions: This tweet expresses bad things like attacking Biden and China. In other words, expressing Biden's failure and using the term "China Virus" can be regarded as bad acts.

2. Preparatory Conditions (PCs): Trump plays the role of being control over Biden and China.

3. iii. Essential Conditions (ECs): (i)Trump has the intention to perform bullying over Biden and China. (ii) Biden and Chinese people realize that they are harmed by Trump's speech.

4. Sincerity Conditions (SCs): Since the above conditions are satisfied, it is clear that bullying is sincerely performed.

\section{Impoliteness Strategies}

\section{1) Bald on record impoliteness}

Here, Trump explicitly threatens the face of Biden and Chinese people. Futher, his threatening is performed intentionally.

\section{2) Positive impoliteness}

Mainly, Trump wants to attack the positive face of Biden and Chinese people when he describes Biden as a failure and when he refers to Corona Virus as China Virus. Attacking positive face is done through being unsympathetic.

\section{3) Negative impoliteness}

Here, Trump tries to attack the negative face of Biden and Chinese people. In other words, he wants to attack them and prevents them from being free from being criticized or mocking on.

\section{4) Off-record impoliteness}

Actually, this strategy is existed in Trump's tweet when he describes Biden as "Gang that can't shoot". More clearly, Trump tries to say that Biden has no benefit like a useless gang which can't shoot.

\section{5) Withhold politeness}


This tweet has no the sense of politeness since Trump speaks aggressively.

\section{Implicature}

Trump's description of Biden as "gang that can't shoot" implies that Biden has no benefit for America like a gang that can't shoot. The type of implicature in this tweet is of conventional implicature.

Tweet (3)

Donald J. Trump

@realDonaldTrump

So ridiculous. Greta must work on her Anger Management problem, then go to a good old fashioned movie with a friend! Chill Greta, Chill!

\section{(9) Roma Downey @ @ealRomaDowney Congrats@GretaThunberg twitter.com/TIME/status/12...}

\section{Speech Act}

1. Propositional Content Conditions: Trump talks badly about a girl called Greta who criticizes him for his policy during Corona Virus.

2. Preparatory Conditions (PCs): Trump is the controller over Greta.

3. Essential Conditions (ECs): (i) Trump has the intention to perform bullying over Greta. (ii) Greta realizes that she is harmed by Trump's speech.

4. Sincerity Conditions (SCs): Since the above conditions are satisfied, it is clear that bullying is sincerely performed.

\section{Impoliteness Strategies}

\section{1) Bald on record impoliteness}

Here, threatening Greta face is performed directly and intentionally by Trump.

\section{2) Positive impoliteness}

Attacking Greta positive face is Trump's aim. He does that by being unsympathetic with using unsuitable identity markers.

\section{3) Negative impoliteness}

Having the power upon Greta, Trump tries to attack her freedom in expressing her thoughts by using mocking language.

\section{4) Off-record impoliteness}

According to this strategy in this tweet, Trump performs FTA explicitly. As such, there is no chance for off-record to occur here.

\section{4) Withhold politeness}


In this tweet we have no politeness. That is, the sense of impoliteness is clearly occurred. In other words, Trump clearly is impolite with Greta when describing her as an old one or ridiculous.

\section{Implicature}

In this tweet, Trump uses implicature when describing Chill Greta as CHILL. In other words, through this implicature, Trump wants to mock from Greta who seems chill.

\section{Tweet (4)}

\section{(2x) Donald J. Trump @realDonaldTrump \\ Sleepy Joe Hiden' was acknowledged by his own people to have done a terrible job on a much easier situation, H1N1 Swine Flu. The OBiden Administration failed badly on this, \& now he sits back in his basement and criticizes every move we make on the China Virus. DOING GREAT JOB!}

\section{Speech Act}

1. Propositional Content Conditions: The acts being performed, here, are something bad. That is, using the terms "Sleepy Joe Hiden" and "China Virus" are bad.

2. Preparatory Conditions (PCs): Trump plays the role of being control over Joe Biden and China.

3. iii. Essential Conditions (ECs): (i) Trump has the intention to perform bullying over Biden and China. (ii) Joe Biden and Chinese people realize that they are harmed by Trump's speech.

4. Sincerity Conditions (SCs): Since the above conditions are satisfied, it is clear that bullying is sincerely performed.

\section{Impoliteness Strategies}

\section{1) Bald on record impoliteness}

Directly, Trump threatens the face of Joe Biden and Chinese people for attributing the virus of corona for them.

\section{2) Positive impoliteness}

Here, Trump attacks Joe Biden and Chinese people's positive face. He expresses his attacking by using the strategy of being unsympathetic with using some unsuitable identity markers like Hiden for Biden as a marker of insulting.

\section{3) Negative impoliteness}

Additionally, Trump succeeds in attacking the negative face needs of Biden and Chinese people to be free from Trump criticism. He does this strategy by using mocking and belittling. In other words, he describes Biden as "sleepy and hiden" to express that he has no role through Covid-19 crisis.

4) Off-record impoliteness 
Here, Trump tends to perform FTA implicitly. In other words. When Trump describes Biden's work as "DOING GREAT JOB", he means the opposite, i.e. ironically he uses it.

\section{5) Withhold politeness}

Having a look on the above tweet, it is clear that Trump behave impolitely when he mocks Biden and Chinese people.

\section{Implicature}

In this tweet, Trump uses implicature more than once. Firstly, it is used when Trump describes Biden as "sleepy" and "Hiden" to imply that Biden is a useless leader. The type of implicture, here, is conventional.

Tweet (5)
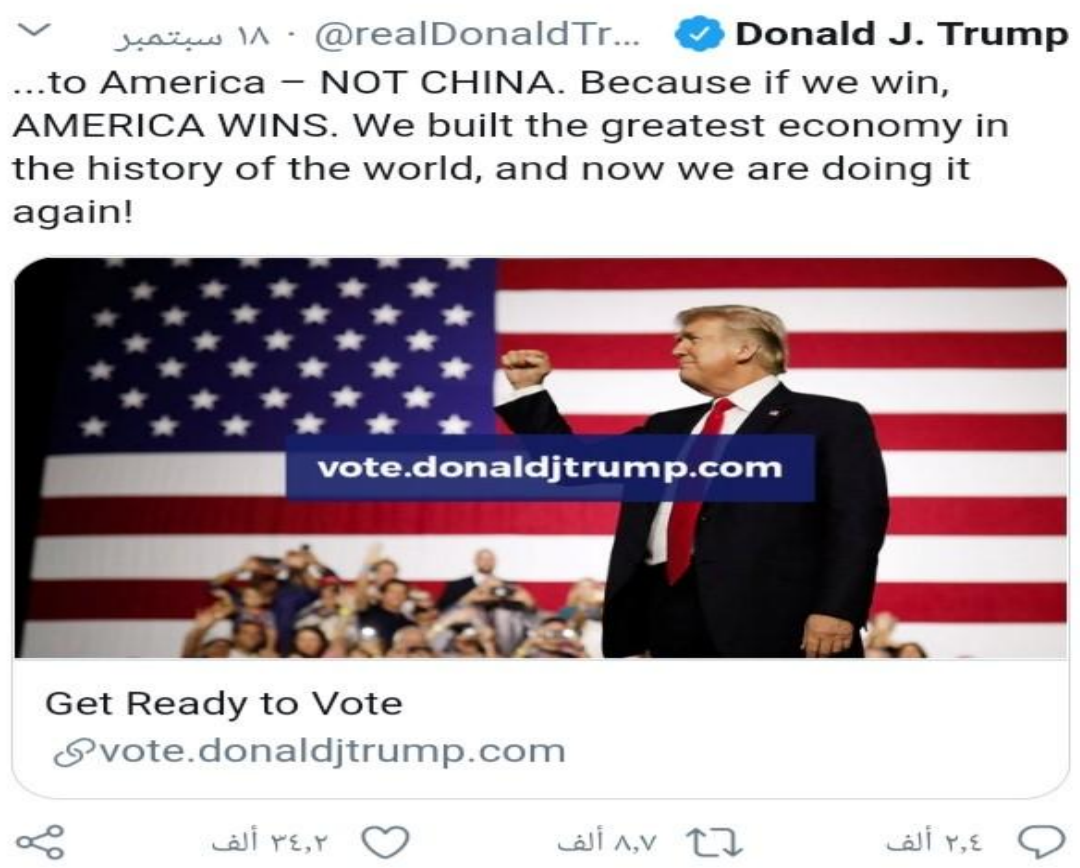

\section{Speech Act}

1. Propositional Content Conditions: Trump's act is a bad one. More clearly, saying that "to America not China", Trump tries to express his hate to China in one hand, and to indicate that as if Biden is an ally to China. So, if Biden wins, it means that China will have a chance to interfere in America affairs.

2. Preparatory Conditions (PCs): Trump plays the role of being control over China.

3. iii. Essential Conditions (ECs): (i) Trump has the intention to perform bullying over China. (ii) Chinese people realize that they are harmed by Trump's speech.

4. Sincerity Conditions (SCs): Since the above conditions are satisfied, it is clear that bullying is sincerely performed.

\section{Impoliteness Strategies}

\section{1) Bald on record impoliteness}

Directly, Trump threatens the face of China for accusing them in an issue that they may have no role with it.

\section{2) Positive impoliteness}


Here, Trump attacks Chinese people's positive face. He expresses his attacking by using the strategy of ignoring them or even not interested within them.

\section{3) Negative impoliteness}

According to the above tweet, Trump has not used it.

\section{4) Off-record impoliteness}

Here, Trump tends to perform FTA implicitly. In other words. When he compares between America and China in favor to America, implicitly he tries insult them.

\section{5) Withhold politeness}

Having a look on the above tweet, it is clear that Trump behave impolitely through the made comparison via him.

\section{Implicature}

The used implicature, according to tweet (5), is embodied in Trump's saying "and we will do it again." In other words, he wants to say that he will win for the second time in the elections.

\section{Results and Discussion}

To have accurate results with a good discussion, the paper tends to presents some tables to show the percentages for each used notion in the analysis with its discussion.

Table 1. Shows occurrences of speech act of bullying

\begin{tabular}{|l|l|l|l|}
\hline No. & Speech Act Theory & Frequency & Percentage \\
\hline 1 & Speech act of bullying & 5 & $100 \%$ \\
\hline 2 & Total & 5 & $100 \%$ \\
\hline
\end{tabular}

As it has been expressed in the theoretical part, we cannot consider the speech as bullying unless the felicity conditions of bullying are applicable to such act. According to the analysis, all the selected tweets have the speech act of bullying, whether implicitly or explicitly. As such, the percentage of bullying, here, is $100 \%$.

Table 2. Shows occurrences of impoliteness strategies

\begin{tabular}{|l|l|l|l|}
\hline No. & Impoliteness Strategies & Frequency & Percentage \\
\hline 1 & Bald on record impoliteness & 5 & $100 \%$ \\
\hline 2 & Positive impoliteness & 5 & $100 \%$ \\
\hline 3 & Negative impoliteness & 4 & $80 \%$ \\
\hline 4 & Off-record impoliteness & 4 & $80 \%$ \\
\hline 5 & Withhold politeness & 5 & $100 \%$ \\
\hline
\end{tabular}

According to the above table, there is a variable use for the strategies of impoliteness used by Trump. In other words, some of strategies are used in most of Trump's tweets like (Bald on record impoliteness, positive impoliteness, and withhold politeness). These strategies are of $100 \%$ percent. Whereas, (negative impoliteness and off-record impoliteness) strategies are used usually. That is, they are of $80 \%$ percent. 
Table 3. Shows occurrences of implicature

\begin{tabular}{|l|l|l|l|}
\hline No. & Implicature & Frequency & Percentage \\
\hline 1 & Implicature & 4 & $80 \%$ \\
\hline 2 & Total & 4 & 80 \\
\hline
\end{tabular}

Actually, Trump is known for his direct and aggressive manner in speech. As such, most of speech or critics is performed directly. Yet, sometimes, he criticizes implicitly. Such implicit criticizing or bullying is done in a form of implicature. Implicature is of $80 \%$ percentage.

\section{Conclusions}

The present paper has reached the following conclusions:

1. Bullying is a bad act used heavily by Trump especially with those who oppose him like China and Biden or anyone else.

2. When Trump wants to bully someone, especially Joe Biden and China, he uses direct strategies. This indicates that he is a harsh character.

3. Since bullying is the opposite of politeness, we find that Trump uses certain strategies for impoliteness like (Bald on record impoliteness, Positive impoliteness, Negative impoliteness, Offrecord impoliteness, and Withhold politeness).

4. Implicature is used, sometimes, in his speech to cover his mocking manner.

\section{References}

Black, Elizabeth. (2006). Pragmatic Stylistics. Edinburgh University Press.

Brown, Gillian and George Yule. (1983). Discourse Analysis. CUP.

Brown, P and Levinson, S. C. (1987). Politeness: Some Universals in Language Usage. Cambridge University Press.

Culpeper, J. (1996). Towards an Anatomy of Impoliteness. Journal of Pragmatics, 25, 349-367.

Culpeper, J. (2011). Impoliteness: Using Language to Cause Offence. Cambridge University Press.

Culpeper, J., Derek B., Anne W. (2003). Impoliteness Revisited with Special Reference to Dynamic and Prosodic Aspects. Journal of Pragmatics, 35, 1545 - 1579.

Cutting, J. (2003). Pragmatics and Discourse: A Resource Book for Students. Routledge

Donegan, Richard. (2012). Bullying and Cyberbullying: History, Statistics, Law, Prevention and Analysis. In The Elon Journal of Undergraduate Research in Communications, 3(1), Spring

Goffman, E. (1967). Interaction Ritual. Chicago: Aldine Publishing.

Harper, D. (2008, October 10). Online etymology dictionary. Retrieved from http://www.etymonline.com/index.php?allowed_in_frame=0\&search=bully\&searchmode=none

Hargittai\& Eszter Hsieh, Yu-Li P. (2011): From Dabblers to Omnivores. In: Papacharissi, Zizi (ed.) (2011): A Networked self: Identity, Community, and Culture on Social Network Sites. Routledge: 146-168.

Leech, G. (1983). Principles of Pragmatics. Longman. 
Wright, Richard A. (1975). "Meaning non-natural and Conversational Implicature", Cole and Morgan. Syntax and Semantics Vol. 3: Speech Act. Academia Press.

Yule, G. (1996). Pragmatics. Oxford University Press.

\section{Websites}

1. https://www.merriam webster.com/dictionary/cyber bullying \# legal Dictionary

\section{AUTHOR BIO DATA}

Asst. Prof. Dr. Hussain Hameed Mayuuf from University of Babylon/ Iraq. I am the Head of the Department of English and a teaching staff member in the higher studies program. I teach Semantics, Pragmatics and Discourse Analysis. I have supervised many MA and PhD Theses and Dissertations. Now I am the Coordinator of the English Department. I have tens of published and unpublished paper. Further, I have participated in a large number of local and international conferences.

Asst. lect. Ibtihal Jasim Abbas from M.A. in Linguistics, Department of English, College of Education for Human Sciences, University of Babylon, 2017 (conducted a thesis entitled "A Pragmatics Study of Vow in Biblical Verses"). I am a Ph.D. student, Department of English, College of Education for Human Sciences, University of Babylon. I teached at the Department of English, College of Education for Human Sciences/ University of Babylon for one year at 2017-2018. I teached at the department of English, college of Imam Kadhum for Islamic Sciences, Sections of Babil from 2017-2020. Further, I have published some papers and a book as coauthored works. 